Eurasscience Journals

Eurasian Journal of Forest Science (2017) 5(1): 29-34

\title{
EFFECT OF THE VARIOUS DOSES OF VERMICOMPOST IMPLEMENTATION ON SOME HEAVY METAL CONTENTS (Cr, Co, Cd, Ni, Pb) OF CUCUMBER (Cucumis sativus L.)
}

\author{
Sevinç Adiloğlu ${ }^{1}$, Korkmaz Bellitürk ${ }^{\text {, Yusuf Solmaz }}{ }^{1}$, Ali Zahmacıoğlu¹, Arıkan Kocabaş², Aydın \\ Adiloğlu1 \\ ${ }^{1}$ Namık Kemal University, Faculty of Agriculture, Department of Soil Science and Plant Nutrition, \\ Tekirdağ/Turkey. \\ ${ }^{2}$ Republic of Turkey Ministry of Food, Agriculture and Livestock, Çanakkale Food Control Laboratory, \\ Çanakkale/Turkey.
}

\begin{abstract}
In this study, the effects of the increasing doses of vermicompost implementation [0\% (VC1), $3 \%$ (VC2), $5 \%$ (VC3), $7 \%$ (VC4)] on some heavy metal contents of cucumber (Cucumis sativus L.) have been investigated. With the increasing doses of vermicompost implementation, $\mathrm{Cr}, \mathrm{Co}, \mathrm{Cd}, \mathrm{Ni}$ and $\mathrm{Pb}$ contents of cucumber decreased. While the Cr content of cucumber is $65.94 \mathrm{mg} / \mathrm{kg}$ with the implementation of VC1 (control) dose, it decreases to $20.58 \mathrm{mg} / \mathrm{kg}$ with VC4 dose. The plant's $\mathrm{Co}, \mathrm{Cd}$, Ni and Pb contents decreases with the increasing doses of vermicompost implementation, as well, VC1-VC4 doses of vermicompost are determined for Co, Cd, Ni and also $\mathrm{Pb}$ as 7.66-2.09, 1.05-0.71, 47.93- 14.57 and also 15.68- $5.01 \mathrm{mg} / \mathrm{kg}$ respectively. These results revealed that vermicompost can be used as a fertilization program to protect the plant's quality and to eliminate its heavy metal contents. On the other hand, the use of organic fertilizers such as vermicompost should be extended for the maintenance of soil productivity.
\end{abstract}

Key words: Cucumber (Cucumis sativus L.), heavy metal, vermicompost.

Özet

Bu çalışmada farklı vermikompost dozlarının [0 \% (VC1), $3 \%$ (VC2), $5 \%$ (VC3), 7 \% (VC4)], salatalık (Cucumis sativus L.) bitkisindeki metal konsantrasyonlarına etkisi araştııllmıştır. Vermikompost dozu artışına bağlı olarak salatalıklardaki $\mathrm{Cr}, \mathrm{Co}, \mathrm{Cd}$, Ni ve Pb konsantrasyonlarında düşüş tespit edilmiştir. Kontrol uygulamasındaki VC1 Cr $65.94 \mathrm{mg} / \mathrm{kg}$ olarak tespit edilmiş, ancak \%7 (VC4) vermikompost uygulanan salatalıkta bu miktar 20.58 $\mathrm{mg} / \mathrm{kg}$ ’a düșmüștür. VC1-VC4 uygulamalarına tabi tutulan salatalık bitkilerinde $\mathrm{Co}, \mathrm{Cd}$, Ni ve Pb miktarları sirasıyla 7.66-2.09, 1.05-0.71, 47.93- 14.57 ve $15.68-5.01 \mathrm{mg} / \mathrm{kg}$ olarak değişmiştir. Elde edilen sonuçlar, vermikompost, bitki kalitesini korumak ve bitkideki ağır metal miktarını düşürmek amacı güden gübreleme programlarında kullanılabileceğini göstermektedir. Diğer yandan ise, vermikompostun aynı zamanda toprak verimliliğini sürdürebilmek için de kullanılması mümkündür.

Anahtar kelimeler: Ağır metal, salatalık (Cucumis sativus L.), vermikompost. 


\section{INTRODUCTION}

Today, it has been a must to obtain higher yield from per unit area in order to fulfill humankind's need for food, which leads to the application of more inorganic fertilizers. As a result of the excessive use of inorganic and chemical fertilizer, natural sources, soil and water sources are being highly polluted and serious health problems occur.

In recent years, the scientists who search for a solution for this problem have suggested that the use of organic fertilizers should be increased. Because, besides the fact that organic fertilizers are nutrient sources, they can also regenerate the quality deficiencies in soil and water sources. Recently, in vegetable farming the use of organic fertilizers have being widely used, especially vermicompost (Adiloğlu et al., 2015, Adiloğlu and Sağlam, 2015; Bellitürk, 2016). In addition, vermicompost is good for soils which have heavy metal problems, and for their regeneration (Bellitürk et al., 2015).

Generally, higher doses of chemical fertilizers are applied per unit area to improve yield in vegetable farming like in other agricultural activities (Adediran et al. 2004, Naeem et al., 2006, Dauda et al., 2008).

In a research the effects of the increasing doses of vermicompost implementation on the yield of potato plant, $0,4.5,9$ and 12 ton/da vermicompost were applied. As a result, the highest levels of height, dry weight of leaf and trunk, dry and wet tuber weight, number of tubers, tuber diameter, tuber nitrogen proportion and tuber potassium proportion are obtained from 12 ton/da vermicompost implementation (Yourtchi et al., 2013).

In a research conducted by Haghighi et al. (2016), the effects of vermicompost on tomato's (Lycopersicum esculentum L.) some quality parameters such as the number of fresh fruit, root development, amount of dry matter, and average yield were determined. At the end of the test, a parallel was found between the increasing doses of vermicompost implementation and tomato's calculated parameters.

In India, a study was carried out to identify the effects of the increasing doses of vermicompost implementation on pineapple's (Ananas comosus L.) some quality parameters (Chaudhuri, 2016). The test lasted for 30 months. The vermicompost doses were applied to the plants as $0,5,10,20$ and 30 ton /ha/year. At the end of the test, the highest levels of the plant's average leaf width and height, the number of leaves, the average fruit diameter, and fruit yield were found on the 20 ton/ha/year dose. These results show that vermicompost organic fertilizer has a significant influence on quality parameters of pineapple.

In a research conducted in China under greenhouse conditions, the amounts of $\mathrm{Cd}$, As, $\mathrm{Hg}, \mathrm{Pb}, \mathrm{Cu}$ and $\mathrm{Zn}$ in various vegetables' root, trunk and leaves were examined. Consequently, the highest level of heavy metal accumulation was observed in the roots of the plants. It was also seen that, some chemical elements of soil were influential on the heavy metal contents of the plant, and especially with the increase of the absorption of the organic matter in soil, the levels of heavy metal decreased ( $\mathrm{Hu}$ et al., 2017).

Some heavy metal absorptions of cucumber and tomato were determined with an experiment carried out under greenhouse and open field conditions (Li et al., 2017). It has been revealed that $\mathrm{Cu}, \mathrm{Zn}, \mathrm{Fe}, \mathrm{Mn}, \mathrm{Pb}$ and $\mathrm{Cd}$ concentrations are higher in the tissues of cucumber and tomato that grew in greenhouse conditions.

In this study, which was conducted under greenhouse conditions, the effects of the increasing doses of vermicompost implementation on cucumber's some heavy metal contents $(\mathrm{Cr}, \mathrm{Co}, \mathrm{Cd}, \mathrm{Ni}$ and $\mathrm{Pb}$ ) have been investigated.

\section{MATERIAL AND METHOD}

The experiment was carried out at the Faculty of Agriculture, Namık Kemal University, Soil Science and Plant Nutrition Department, Tekirdağ, Turkey. The experiment is conducted under greenhouse conditions as a viol test, and organized according to the randomized parcel design with 3 replicates with the design of $0 \%$ (VC1), 3\% (VC2), 5\% 
(VC3), 7\% (VC4) and also VC means vermicompost in this experiment. The vegetable seeds which have been used for the experiment were obtained from a special company. Testing plants are harvested on the $40^{\text {th }}$ day after planting, and necessary analyses of cucumber (only plant shoot) are completed. The heavy metal contents were determined in ICP-OES device (Kacar and İnal, 2010).

Organic matter, $\mathrm{pH}, \mathrm{EC}$, lime, useful phosphor, transfusable potassium, total nitrogen (Sağlam, 2012), texture (Demiralay, 1993), extractable heavy metals (Cr, Co, Cd, Ni and $\mathrm{Pb}$ ) (Lindsay and Norvell, 1978) of the sample soil have been analyzed.

Some physical and chemical analysis results of the sample soil have been presented on the Table 1 below.

Table 1. Some physical and chemical analysis results of the sample soil.

\begin{tabular}{|c|c|}
\hline Soil parameters & Analysis results \\
\hline $\mathrm{pH}(1: 2.5$ soil: water $)$ & 7.25 \\
\hline $\mathrm{EC}(\mathrm{dS} / \mathrm{m})$ & 0.08 \\
\hline $\mathrm{CaCO} 3(\%)$ & 1.15 \\
\hline Organic matter $(\%)$ Texture class & 0.86 \\
\hline $\mathrm{N}(\%)$ & $\mathrm{Clay}$ \\
\hline $\mathrm{P}\left(\mathrm{mgkg}^{-1}\right)$ & 0.04 \\
\hline $\mathrm{K}\left(\mathrm{mgkg}^{-1}\right)$ & 5.72 \\
\hline $\mathrm{Cd}\left(\mathrm{mgkg}^{-1}\right)$ & 69.16 \\
\hline $\mathrm{Ni}\left(\mathrm{mgkg}^{-1}\right)$ & BDL \\
\hline $\mathrm{Cr}\left(\mathrm{mgkg}^{-1}\right)$ & BDL \\
\hline $\mathrm{Co}\left(\mathrm{mgkg}^{-1}\right)$ & BDL \\
\hline $\mathrm{Pb}\left(\mathrm{mgkg}^{-1}\right)$ & BDL \\
\hline
\end{tabular}

The $\mathrm{pH}$ level of the soil has a neutral character, and the soil itself does not contain salt and lime. Soil texture class is clay, and soil has low organic matter, on the other hand soil N, P, and $\mathrm{K}$ contents are low. The extractable heavy metal contents ( $\mathrm{Cr}, \mathrm{Co}, \mathrm{Cd}, \mathrm{Ni}$ and $\mathrm{Pb}$ ) of the sample soil are below the evaluation limits (Lindsay and Norvell, 1969; FAO, 1990; Tovep, 1991; Güneş et al., 2010).
The vermicompost which is not include any heavy metal (because it is rule of vermicompost producing regulation), is used as the organic fertilizer material is provided from a special company and the analysis results are presented below (Table 2).

Table 2. Some chemical properties of vermicompost fertilizers (does not include any heavy metals).

\begin{tabular}{|c|c|c|c|c|c|c|c|}
\hline Sample & $\mathrm{pH}$ & $\begin{array}{c}\text { Org. } \\
\mathrm{M} . \%\end{array}$ & $\begin{array}{c}\mathrm{N} \\
\%\end{array}$ & $\begin{array}{c}\mathrm{P} \\
\%\end{array}$ & $\begin{array}{c}\mathrm{K} \\
\%\end{array}$ & $\begin{array}{c}\mathrm{Ca} \\
\%\end{array}$ & $\begin{array}{c}\mathrm{Mg} \\
\%\end{array}$ \\
\hline $\begin{array}{c}\text { Verm. } \\
\text { (VC) }\end{array}$ & 7.28 & 44.10 & 1.97 & 1.01 & 1.69 & 0.71 & 0.02 \\
\hline
\end{tabular}

\section{RESULTS AND DISCUSSION}

The heavy metal results gathered from the test have been given on the Table 3 and Figure 1 below. When the Table 3 is examined, it can be observed that all heavy metal contents of the plant decrease with the increasing doses of vermicompost implementation. This can also be seen from the Figure 1.

Table 3. The Effects of the increasing doses of Vermicompost Application on Some Heavy Metal Contents (Cr, Co, Cd, Ni, Pb) of Cucumber (Cucumis sativus L.)

\begin{tabular}{|c|c|c|c|c|c|}
\hline Cucumber & $\mathbf{C r}$ & $\mathbf{C o}$ & $\mathbf{N i}$ & $\mathbf{C d}$ & $\mathbf{P b}$ \\
\hline VC1 & 65.94 & 7.66 & 47.93 & 1.05 & 15.68 \\
\hline VC2 & 44.35 & 5.30 & 33.12 & 0.71 & 8.72 \\
\hline VC3 & 19.10 & 2.48 & 15.70 & 0.63 & 5.10 \\
\hline VC4 & 20.58 & 2.09 & 14.57 & 0.71 & 5.01 \\
\hline
\end{tabular}

With the increasing doses of vermicompost implementation, $\mathrm{Cr}$ contents of cucumber plant decrease significantly. While the $\mathrm{Cr}$ content of cucumber is $65.94 \mathrm{mg} / \mathrm{kg}$ with the implementation of VC1 (control) dose, it decreases to $20.58 \mathrm{mg} / \mathrm{kg}$ with VC4 dose, which is caused by the excessive absorption of $\mathrm{Cr}$ in the soil by organic matters, and the increasing amount of vermicompost (Adiloğlu et al., 2015a). 


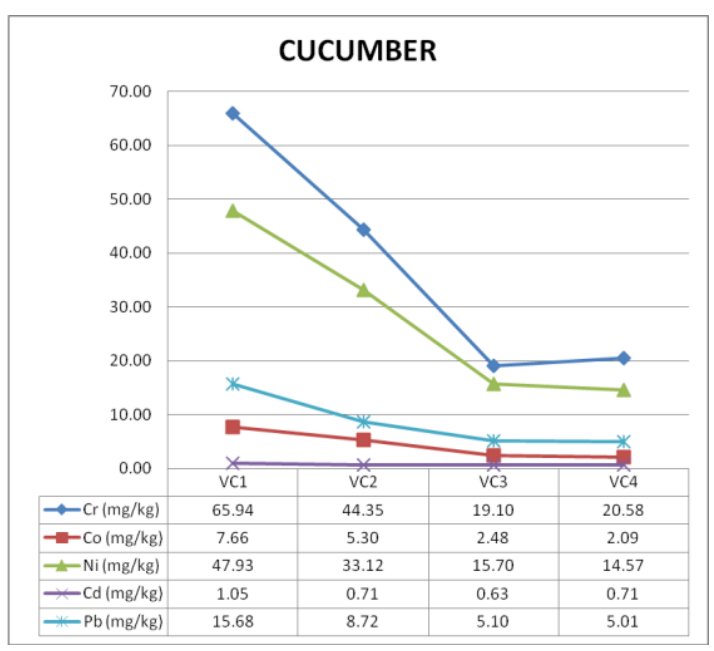

Figure 1. The effect of vermicompost application on $\mathrm{Cr}, \mathrm{Co}, \mathrm{Ni}, \mathrm{Cd}$ and $\mathrm{Pb}$ contents.

When the effects of vermicompost on Co contents of the plant are analyzed, it can be concluded that with the increasing doses of vermicompost implementation, Co contents decrease significantly (Table 3, Image 1). While the Co content of cucumber is $7.66 \mathrm{mg} / \mathrm{kg}$ with the VC1 (control) dose, it decreases to $2.09 \mathrm{mg} / \mathrm{kg}$ with VC4 dose. Some heavy metals such as cobalt, form complexes with organic matters as the organic matter in soil increases, and their absorption by the plants reduces (Adiloğlu, 2016; Li, 2017).

With the increasing doses of vermicompost implementation, $\mathrm{Ni}$ contents of cucumber plant decrease significantly (Table 3). While the $\mathrm{Ni}$ content of cucumber is $47.93 \mathrm{mg} / \mathrm{kg}$, it decreases to $14.57 \mathrm{mg} / \mathrm{kg}$ with highest vermicompost dose (VC4). The absorption of some heavy metals such as $\mathrm{Ni}$ increases as the organic matter in soil increases, and their absorption by the plants reduces (Adiloğlu et al., 2016; Haghighi et al., 2016).

The change in $\mathrm{Cd}$ contents of cucumber plant with the increasing doses of vermicompost implementation can be seen from the Figure 1. When the Figure is examined, it can be observed that $\mathrm{Cd}$ contents of the plant decrease with the increasing doses of vermicompost implementation. While the $\mathrm{Cd}$ content of cucumber is $1.05 \mathrm{mg} / \mathrm{kg}$ VC1(control) dose, it decreases to $0.71 \mathrm{mg} / \mathrm{kg}$ with highest vermicompost dose (VC4), which is caused by the fact that the increase of the organic matter also increases the $\mathrm{Cd}$ absorption, and its accumulation in the soil (Adiloğlu et al., 2016a; Chaudhuri et al., 2016).

The effects of the increasing doses of vermicompost implementation on the plant's $\mathrm{Pb}$ content have been presented on the Table 3. When the effects of vermicompost on $\mathrm{Pb}$ contents of the plant are analyzed, it can be concluded that with the increasing doses of vermicompost implementation, $\mathrm{Pb}$ contents decrease significantly (Table 3). While the $\mathrm{Pb}$ content of cucumber is $15.68 \mathrm{mg} / \mathrm{kg}$ with the VC1 (control) dose, it decreases to $5.01 \mathrm{mg} / \mathrm{kg}$ with VC4 dose (Image 1). With the high levels of organic matter in soil, the absorption of heavy metals by the plants increases and a decrease occurs in its removal from the soil (Hu et al., 2017; Li et al., 2017).

\section{CONCLUSION}

There has been organic matter inefficiency in most part of the agricultural fields in Turkey, which makes the improvement of the amount of organic matter in these lands a necessity. The idea of the extension of vermicompost in agriculture will be a solution by contributing to the increase of organic matter in soil, and by being an important input for providing nutrients to the plants. Also, with the extension of vermicompost in agricultural production, the pollution and nutrition balance distortions caused by chemical fertilizers will be regenerated. In this study, it has been revealed that vermicompost is an important organic material source for regeneration and prevention of heavy metal pollution, and for the protection and improvement of quality and yield. Vermicompost is also an important natural source in the maintenance of the yield of agricultural lands.

\section{Conflict of Interests}

The authors have not declared any conflict of interests.

\section{References}

Adediran A.J., Taiwo B.L., Akande O.M., Sobule A.R., Idowu J.O., 2004. Application of organic and inorganic fertilizer for sustainable maize and cowpea yields in Nigeria, J. Plant Nutr., 27: 1163-1181.

Adiloğlu S., Adiloğlu, A., Acikgoz, F.E. Yeniaras T., Solmaz Y., 2016a. Phytoremediation of Cadmium (Cd) from Agricultural Soils Using 
Dock (Rumex patientia L.) Plant. Analytical Letters. DOI:10.1080/00032719.2015.1075132. 49 (4): 601-606.

Adiloğlu A., Eryilmaz Açıöz F., Adiloğlu S., Solmaz Y., 2015. Akuakültür Atığ1 ve Solucan Gübresi Uygulamalarının Salata (Lactuca sativa L. var. crispa) Bitkisinin Verim, Bazı Bitki Besin Elementi İçeriği ile Bazı Agronomik Özellikleri Üzerine Etkisi. Namık Kemal Üniversitesi Araştırma Projesi No: 00.24.AR.15.11

Adiloğlu S., Sağlam M.T., 2015. Tekirdağ İlinde Karayolu Kıyısındaki Toprakların Organik Madde Miktarları. KSÜ Doğa Bilimleri Dergisi, pp. 49-60.

Adiloğlu, S., 2016. Phytoremediation of Cobalt (Co) From Agricultural Soils Using Canola (Brassica napus L.) Plant. Removal of Cobalt (Co) from the Agricultural Soils with Canola (Brassica napus L.) Using Phytoremediation Method. Polish Journal of Environmental Studies, Vol. 25 (6): 2251-2254.

Adiloğlu S., Sağlam M.T., Adiloğlu A., Süme A., 2016. Removal of Nickel (Ni) from Agricultural Field Soils by Phytoremediation using Canola (Brassica napus L.). 2nd International Conference on Recycling and Reuse. İstanbul, 4-6 June 2014. Desalination and Water Treatment. Vol: 57 (6): 2383-2388.

Adiloğlu S., Sağlam M.T., Süme A., 2015a. Chrome (Cr) Pollution in Agricultural Areas Improvement by Phytoremediation Method with Canola (Brassica napus L.) Plant Growing. Journal of Essential Oil Bearing Plants. Vol: 18 (5): 1180-1186

Arisha H.M.E., Gad A.A., Younes S.E., 2003. Response of some pepper cultivars to organic and mineral nitrogen fertilizer under sandy soil conditions, Zagazig J. Agric. Res., 30: 18751899.

Badr L.A.A., Fekry W.A., 1998. Effect of intercropping and doses of fertilization on growth and productivity of taro and cucumber plants. Vegetative growth and chemical constituents of foliage, Zagazig J.Agric. Res., 25: 1087-101.

Bellitürk K., 2016. Sürdürülebilir Tarımsal Üretimde Kat1 Atık Yönetimi İçin Vermikompost Teknolojisi. (7. Ulusal Bitki Besleme ve Gübre Kongresi, 12-15 Ekim 2016) Çukurova Tarım ve Gida Bilimleri Dergisi, 31 (3): 1-5 (Özel Say1), Adana.

Bellitürk K., Shrestha P., Görres J.H., 2015. The Importance of Phytoremediation of Heavy Metal Contaminated Soil Using Vermicompost for Sustainable Agriculture. Rice Journal 3:2, 6: e114, doi: 10.4172/2375-4338.1000e114

Chaudhuri P.S., Paul T.K., Dey A., Datta M, Dey S.K. 2016. Effects of rubber leaf litter vermicompost on earthworm population and yield of pineapple (Ananas comosus L.) in West Tripura, India. International Journal of Recycling of Organic Waste in Agriculture, 5: 93-103.

Dauda S.N., Ajayi F.A., Ndor E., 2008. Growth and yield of water melon (Citrullus lanatus L.) as affected by poultry manure application, J. Agric. Soc. Sci., 4: 121-124.

FAO (1990). Micronutrient Assesment at the Country Level: An International Study, FAO Soils Bulletin 63, Rome.

Greweling T., Peech M., 1960. Chemical Soil Tests, Cornell Univ. Agric. Exp. Stn. Bull. No: 960, USA.

Güneş A., Alpaslan M., İnal A., 2010. Bitki Besleme ve Gübreleme, A.Ü. Ziraat Fak. Yayınları, Yayın No:1581, Ankara.

Sağlam M.T., 2012. Toprak ve Suyun Kimyasal Analiz Yöntemleri, Namık Kemal Üniversitesi, Yayın No: 2, Tekirdağ.

Düzgüneş O., Kavuncu O., Kesici T., Gürbüz F., 1987. Araştırma ve deneme metodları. A.Ü. Ziraat Fakültesi Yayınları, No: 1021, Ankara.

Haghighi M., Barzegar R.M, Jaime A., Silva T., 2016. The effect of municipal solid waste compost, peat, perlite and vermicompost on tomato (Lycopersicum esculentum L.) growth and yield in a hydroponic system. International Journal of Recycling of Organic Waste in Agriculture, 5: 231-242.

Hu W., Huang B., Tian K., Holm P.E., Zhang Y., 2017. Heavy metals in intensive greenhouse vegetable production systems along Yellow Sea of China: Levels, transfer and health risk. Chemosphere, 167: 82- 90.

Kacar B., 2009. Toprak Analizleri (Genişletilmiş 2. Baskı). Ankara. Nobel Yayın Dağıtım Ltd. Şti, s: 209-269.

Li F., Shi W., Jin Z., Wu H., Sheng G.D., 2017. Excessive uptake of heavy metals by greenhouse vegetables. Journal of Geochemical Exploration, 173: 76- 84.

Lindsay W.I., Norwell W.A., 1969. Development of DTPA Micronutrient Soil Test, Soil Sci. Am. Proc. 35: 600-602.

Naeem M., Iqbal J., Bakhsh M.A.A., 2006. Comparative study of inorganic fertilizers and organic manures on yield and yield components of mungbean (Vigna radiat L.), J. Agric. Soc. Sci., 2: 227-229.

Stewart M.W., Dibb W.D., Johnston E.A., Smyth J.T., 2005. The contribution of commercial fertilizer, Nutrients to Food Production. Agron. J., 97: 1-6.

TOVEP, 1991. Türkiye Toprakları Verimlilik Envanteri, TC Tarım Orman ve Köy İşleri Bakanlığ1 Yayınları, Köy Hizmetleri Genel Müdürlüğü, Ankara. 
Yourtchi M.S., Hadi M.H.S., Darzi M.T., 2013.

Effect of nitrogen fertilizer and vermicompost on vegetative growth, yield and NPK uptake by tuber of potato (Agriacv.). Int. J. Agric. Crop Sci. 5 (18): 2033-2040.

Submitted: 22.03.2017

Accepted: 02.06.2017 